\title{
Pengaruh Pemberian Alga Coklat (Sargassum sp.) Terhadap Pertambahan Berat Badan Sapi Bali Jantan
}

\author{
Effect of Brown Algae (Sargassum sp) on Bulls Bali Weight Gain
}

\author{
Rasyidah Mappanganro*, Muh.Basir Paly, Khaerani Kiramang, Rifaldi Nurhidayat \\ Jurusan Ilmu Peternakan, Fakultas Sains dan Teknologi \\ Universitas Islam Negeri Alauddin Makassar \\ *Korespondensi Email: rasyidah.mappanganro@uin-alauddin.ac.id
}

\begin{abstract}
ABSTRAK
Penelitian ini bertujuan untuk mengetahui pengaruh pemberian alga coklat (Sargassum sp.) terhadap pertambahan berat badan sapi bali jantan. Metode penelitian yang digunakan adalah metode percobaan yang dirancang dengan menggunakan uji $\mathrm{t}$ (t-test independent sample), 5 ekor sapi diberikan konsetrat dengan penambahan Sargassum sp. dan 5 ekor lainnya diberikan konsetrat tanpa penambahan Sargassum sp. (kontrol). Parameter yang diukur dalam penelitian ini adalah pertambahan berat badan harian ternak sapi bali jantan. Hasil rataan pertambahan berat badan sapi bali jantan dengan penambahan Sargassum sp. dan tanpa penambahan Sargassum sp. menunjukkan hasil perlakuan tidak berbeda nyata $(\mathrm{P}>0,05)$. Meskipun tidak berbeda nyata $(\mathrm{P}>0,05)$ namun terlihat ada peningkatan dan rataan pertambahan berat badan dengan penambahan Sargassum sp dan terlihat lebih tinggi dibanding tanpa penambahan Sargassum sp.
\end{abstract}

Kata Kunci: Pertambahan Berat Badan, Sapi Bali Jantan, Sargassum sp.

\begin{abstract}
This study aims to determine the effect of giving brown algae (Sargassum sp.) to weight gain in bulls bali cattle. The research method used was an experimental method designed using t-test (independent sample t-test) consisting of 2 treatments, 5 replications, 5 of which were given concentrates plus Sargassum sp. and 5 were given concentrates without the addition of Sargassum sp. (control). The parameters measured in this study are daily weight gain of bulls bali cattle. The average results of weight gain of male bali cattle with the addition of seaweed (Sargassum sp.) and without the addition of sargassum sp seaweed showed that the treatment results were not significantly different $(P>0.05)$. Even though it was not significantly different $(\mathrm{P}>0.05)$ but it was seen that there was an increase and average weight gain with the addition of Sargassum sp. and it appeared higher than without the addition of Sargassum sp.
\end{abstract}

Key words : Male Bali cow, Sargassum sp., Weight gain 


\section{PENDAHULUAN}

Pada umumnya sifat unggul yang diinginkan peternak adalah kecepatan terutama pertumbuhan, kemampuan mengkonsumsi pakan berserat tinggi dan kesuburan reproduksinya. Pertumbuhan ternak sapi selain dipengaruhi faktor genetik, dipengaruhi juga oleh sistem manejemen pemeliharaan, lingkungan serta faktor kesehatan ternak. Pertumbuhan ternak ditandai dengan peningkatan bobot, ukuran, dan adanya perkembangan. Salah salah satu parameter yang digunakan untuk mengetahui pertumbuhan sapi selama kurun waktu tertentu adalah pertambahan berat badan, dan lama penggemukan berpengaruh terhadap pertumbuhan atau pertambahan bobot badan harian. Pertambahan berat badan sapi sangat tergantung pada pakan serta kemampuan ternak dalam memanfaatkan pakan.

Ukuran bobot badan sapi merupakan salah satu indikator ekonomi yang sangat diperlukan dalam peternakan sapi potong, terutama dalam hal produksi dan reproduksi ternak. Pertumbuhan ternak biasanya dapat diukur dengan bobot badan yang bertambah dan besarnya badan dapat diketahui dengan mengukur tinggi dan panjang badan serta lingkar dada. Usaha untuk memaksimalkan produksi ternak yaitu dengan memperhatikan kandungan pakan khususnya protein yang terdapat dalam pakan yang diberikan. Seperti yang telah kita ketahu bahwa protein dalam pakan merupakan senyawa organik yang kompleks yang berfungsi untuk menyediakan asam amino, membangun dan memelihara jaringan dan organ tubuh, menyediakan sumber lemak badan, dan menyediakan energi dalam tubuh. Pentingnya pakan dalam usaha ternak sapi potong karena merupakan bagian yang tidak terpisahkan dan merupakan kunci keberhasilan produksi ternak. Ketersediaan pakan baik dari segi kuantitas dan kualitas sangat perlu diperhatikan secara berkesinambungan sepanjang tahun karena sebanyak hampir 70\% dari makanan ternak ruminansia adalah hijauan.

Bahan pakan dapat digolongkan menjadi dua macam yaitu pakan kasar (hijauan) dan konsetrat. Pakan kasar adalah pakan yang mengandung serat kasar 18\%, jenis pakan kasar (hijauan) antara lain rumput-rumputan, hay, leguminosa, dan silase, sedangkan konsentrat adalah bahan pakan yang mengandung serat kasar kurang dari 18\%, dimana konsentrat mudah dicerna dan merupakan sumber zat pakan utama seperti energi dan protein bagi ternak (Hardianto, 2000). Ketersediaan pakan harus mencukupi kebutuhan ternak, baik yang 
berasal dari hijauan/rumput, maupun pakan konsentrat yang dibuat sendiri atau berasal dari pabrik (Direktorat Jenderal Peternakan, 2000).

Tujuan dari pemberian pakan pada ternak dapat dikelompokkan menjadi dua yaitu makanan perawatan, merupakan pakan yang digunakan untuk mempertahankan hidup dan kesehatan, kemudian makanan produksi untuk pertambahan berat dan pertumbuhan. Pemberian zat-zat pakan yang disajikan harus disesuaikan dengan tujuannya masingmasing.Pakan tambahan atau penguat adalah pakan yang mempunyai kandungan gizi tinggi dengan kandungan serat kasar yang relatif rendah, mudah dicerna dan kaya nilai gizi. Sapi yang sedang digemukkan secara intensif (dikandangkan) perlu diberi pakan tambahan yang cukup, karena usaha penggemukan ditujukan untuk memperoleh tingkat pertumbuhan yang maksimal dalam waktu relatif singkat. Bahan pakan tambahan terdiri dari: dedak halus, jagung giling, bungkil kelapa, tepung ikan, garam, mineral dan lain-lain. Berbagai bahan pakan ini disusun sedemikian rupa untuk mendapatkan kandungan protein kasar 15\%. Manfaat dari pakan tambahan ini adalah untuk mempertahankan hidup dan menjamin kesehatan sapi yang sedang digemukan dan pertumbuhan badan akan lebih cepat (umiyasih dan Anggreany, 2007).

Pakan yang diberikan pada ternak harus memperhatikan ketersediaan dan efisiensi biaya, sehingga perlu adanya pemanfaatan sebagai alternatif pakan ternak yang murah dan mudah dicari (Herry, 2013). Sargassum adalah salah satu genus dari kelompok rumput laut coklat yang merupakan genera terbesar dari Famili Sargassaceae. Jenis-jenis Sargassum sp. yang dikenal di Indonesia ada sekitar 12 spesies, yaitu : Sargassum duplicatum, S. histrix, S. echinocarpum, S. gracilimun, S. obtusifolium, S. binderi, S. policystum, S. crassifolium, S. microphylum, S. aquofilum, S. vulgare, dan S. polyceratium (Rachmat, 1999). Sargassum sp. tersebar luas di Indonesia, tumbuh di perairan yang terlindung maupun yang berombak besar pada habitat batu. Dengan daerah penyebarannya antara lain pulau Jawa, Madura, Sumatera Utara, Lombok, Irian, Aru, Kei, dan Kepulauan Seribu (Putri, 2011).

Sargassum sp. dapat dimanfaatkan sebagai bahan makanan, bahan bakar (fuels), kosmetik (cream pelembab), obat-obatan, pigment, serta bahan makanan tambahan (suplement) (Widowati, 2013). Sargassum sp. mengandung karbohidrat (19,06\%), protein $(5,53 \%),(0,74 \%)$, air $(11,71 \%)$, abu (34,57\%), serat kasar (28,39\%) (Yunizal, 2004). Selain itu juga mengandung polisakarida lain yaitu selulosa yang berkisar antara 23,97 - 35,22 \% (Saputra, 2012). Dengan penguraian di atas maka dipandang perlu untuk melakukan 
penelitian terhadap pertambahan berat badan pada sapi bali jantan dengan pemberian Sargassum sp. sebagai tambahan konsentrat". Sesuai dengan perumusan masalah, maka tujuan dalam penelitian ini adalah untuk mengetahui pengaruh pemberian Sargassum sp terhadap pertambahan berat badan pada sapi bali jantan.

Berdasarkan latar belakang yang telah diuraikan diatas, maka rumusan masalahnya adalah bagaimana peran stratifikasi sosial masyarakat pedesaan terhadap usaha ternak sapi potong. Tujuan dari penelitian ini yaitu untuk mengetahui peran stratifikasi sosial masyarakat pedesaan terhadap usaha ternak sapi potong. Hasil penelitian ini diharapkan dapat dijadikan sebagai sumber informasi kepada berbagai pihak terkait peran stratifikasi sosial masyarakat pedesaan terhadap usaha ternak sapi potong

\section{METODE PENELITIAN}

\section{Jenis dan Lokasi Penelitian}

Penelitian ini dilaksanakan selama 3 bulan bertempat di Usaha Peternakan Rakyat di Desa Pajukukang Kecamatan Lumpangan Kabupaten Bantaeng Sulawesi Selatan.

\section{Sumber dan Metode Pengumpulan Data}

Sapi bali jantan sebanyak 10 ekor, ransum, timbangan, dan kandang. Pakan yang digunakan dalam penelitian ini terdiri dari: rumput gajah, rumput lapang, jerami padi, dedak padi, bungkil kelapa, jagung, tepung alga coklat (Sargassum sp), tepung kulit coklat, molases, mineral,dan garam,. Alat yang digunakan dalam penelitian ini adalah mesin penggiling pakan, ember, karung, kantong plastik, sekop dan timbangan.

Persiapan yang dilakukan sebelum penelitian berupa:

a. Pembuatan pakan konsentrat

1) Pengumpulan alga coklat (Sargassum sp.) diperoleh dari petani rumput laut di kabupaten Takalar Desa Punaga.

2) Pengeringan dilakukan untuk mengurangi kadar air pada alga coklat. Kemudian dilakukan penggilingan dan penghalusan dan bahan lainnya. Setelah itu ditimbang sesuai dengan formulasi ransum.

3) Pencampuran

Tabel 1. Hasil Analisis Proksimat Alga Coklat (Sargassum sp) 


\begin{tabular}{ccccccc}
\hline Pakan & Air & Protein Kasar & Lemak Kasar & Serat Kasar & BETN & Abu \\
\hline Sargassum sp & 17.04 & 12.45 & 0.96 & 12.72 & 36.93 & 36.93
\end{tabular}

Sumber: Laboratorium Kimia Makanan Ternak Jurusan Nutrisi dan Makanan Ternak Fakultas Peternakan Universitas Hasanuddin Makassar. 2017.

Tabel 2. Komposisi Pakan Konsentrat yang Diberikan

\begin{tabular}{llll}
\hline \hline Pakan Perlakuan & \multicolumn{1}{c}{$\begin{array}{c}\text { Bahan Pakan } \\
(\%)\end{array}$} & $\begin{array}{c}\text { Takaran } \\
(\text { Kg/ekor/hari) }\end{array}$ \\
& Dedak Padi & $55 \%$ & 3,025 \\
\multirow{4}{*}{ P0 } & Bungkil Kelapa & $12 \%$ & 0,660 \\
& Jagung & $13 \%$ & 0,715 \\
& Garam & $1 \%$ & 0,055 \\
& Tepung Kulit Kakao & $13 \%$ & 0,715 \\
& Mineral & $1 \%$ & 0,055 \\
& Molases & $5 \%$ & 0,275 \\
& & & \\
& Dedak Padi & $50 \%$ & 2,750 \\
& Bungkil Kelapa & $10 \%$ & 0,550 \\
& Jagung & $10 \%$ & 0,550 \\
& Garam & $1 \%$ & 0,055 \\
& Tepung Kulit Kakao & $10 \%$ & 0,550 \\
& Mineral & $1 \%$ & 0,055 \\
& Molases & $3 \%$ & 0,165 \\
& Sargassum & & 0,825 \\
\hline
\end{tabular}

b. Penimbangan awal

Penimbangan awal dilakukan untuk mengetahui berat badan awal sapi bali jantan sebelum melakukan penelitian.

c. Pemberian pakan :

Pakan konsentrat diberikan sebanyak 5,5 Kg/ekor/hari, dilakukan dua kali dalam sehari yaitu dipagi hari sebanyak $2,5 \mathrm{~kg}$ yang bertujuan untuk meningkatkan palatabilitas dan pada sore hari diberikan kembali sebanyak $3 \mathrm{~kg}$ yang bertujuan untuk meningkatkan efektifitas Alga coklat (Sargassum sp).

d. Penimbangan sisa pakan

Penimbangan sisa pakan konsentrat dilakukan sore hari untuk sisa pakan konsetrat pagi hari dan keesokan paginya untuk sisa pakan konsetrat sore di hari sebelumnya (kemarin).

e. Penimbangan

Penimbangan dilakukan setiap 10 hari, dilakukan untuk mengetahui pertambahan berat badan sapi bali jantan.

f. Penimbangan akhir 
Penimbangan akhir dilakukan pada hari ke 50 tepatnya pada pagi hari untuk mengetahui pertambahan berat badan sapi bali jantan selama penelitian berlangsung

\section{Rancangan Percobaan}

Metode penelitian yang digunakan adalah metode percobaan dengan menggunakan Uji $\mathrm{t}$ ( $\mathrm{t}$-test independent sample) yang terdiri dari 2 perlakuan, 5 ulangan yaitu 5 ekor diberikan konsentrat dan 5 ekor sebagai kontrol. Susunan perlakuan adalah sebagai berikut:

1. Tanpa perlakuan / kontrol (P0) : Konsentrat

2. Dengan Perlakuan (P1) : Konsentrat + Sargassum sp.

\section{Variabel yang diukur}

Parameter yang diukur dalam penelitian ini adalah Pertambahan berat badan harian ternak sapi bali jantan

$$
\mathrm{PBBH}=\frac{\text { BB Akhir Pengamatan }(\mathrm{Kg})-\mathrm{BB} \text { Awal Pengamatan }(\mathrm{Kg})}{\text { Lama pengamatan (Hari) }}
$$

\section{HASIL DAN PEMBAHASAN}

Berdasarkan hasil penelitian diperoleh rataan pertambahan berat badan sapi bali jantan yng dapat dilihat pada Tabel 1. di bawah ini.

Tabel 1. Rataan Pertambahan Berat Badan Sapi Bali Jantan

\begin{tabular}{llllll}
\hline \multirow{2}{*}{ Perlakuan } & \multicolumn{5}{c}{ PBB/ Hari (Penimbangan tiap 10 hari) } \\
& I & II & III & IV & V \\
\hline Tanpa Sargassum sp. (P0) & 0,46 & 0,47 & 0,54 & 0,12 & 0,73 \\
Sargassum sp. (P1) & 0,30 & 0,35 & 0,26 & 0,3 & 0,42 \\
\hline
\end{tabular}

Berdasarkan Tabel 1. di atas, perlakuan P1 (yang diberikan Sargassum sp.) periode 10 hari pertama memiliki pertambahan berat badan lebih tinggi $1.6 \mathrm{~kg}$, dibandingkan sapi tanpa diberikan perlakuan P0 (tanpa Sargassum sp.) pada periode hari ke 2 pertambahan berat badan sapi perlakuan P1 (yang diberikan Sargassum sp.) lebih tinggi $1.2 \mathrm{~kg}$, dibandingkan sapi perlakuan P0 (tanpa pemberian Sargassum sp.) pada periode hari ke 3 pertambahan berat badan sapi perlakuan P1 (yang diberikan Sargassum sp.) lebih tinggi 2.8 kg dibandingkan sapi perlakuan P0 (tanpa pemberian Sargassum sp.) pada periode hari ke 40 pertambahan berat badan sapi perlakuan P1 (yang diberikan Sargassum sp.) lebih rendah 1.8 
kg sedangkan sapi perlakuan P0 (tanpa pemberian Sargassum sp) mengalami penambahan berat badan sebanyak $3 \mathrm{~kg}$ kemudian periode ke 5, pertambahan berat badan sapi perlakuan P1 (yang diberikan Sargassum sp.) lebih tinggi $3.1 \mathrm{~kg}$, dibandingkan dengan sapi perlakuan P0 (tanpa pemberian Sargassum sp.).

Hasil rataan pertambahan berat badan sapi bali jantan dengan penambahan rumput laut (sargassum sp) dan tanpa penambahan rumput laut sargassum sp menunjukkan perlakuan tidak berbeda nyata $(\mathrm{P}>0,05)$ sehingga dapat dikatakan bahwa tidak terdapat perbedaan pertambahan berat badan antara pemberian sargassum sp dengan tanpa pmberian sargassum sp. Meskipun tidak berbeda nyata $(\mathrm{P}>0,05)$ namun terlihat pada gambar 1 linearnya mengalami peningkatan dan rataan pertambahan berat badan penambahan rumput laut (sargassum $\mathrm{sp}$ ) terlihat lebih tinggi dibandingkan tanpa penambahan sargassum sp.

Pertambahan berat badan harian yang diperoleh dari penelitian ini yaitu berkisar antara $0,47-0,73 \mathrm{~kg} /$ hari data ini menggambarkan bahwa penambahan sargassum sp pada pakan konsentrat sapi bali jantan sebanyak 15\% cukup baik, juga menunjukkan bahwa performance yang baik dicapai oleh perlakuan dengan penambahan rumput laut (sargassum sp). Hasil ini sesuai dengan pendapat Pane (1991) yang menyatakan, Sapi bali jantan dewasa mampu mencapai pertambahan bobot badan hingga $0.7 \mathrm{~kg} /$ hari. Hal ini sejalan dengan pendapat Oematan (2000) bahwa sapi bali mampu menghasilkan pertambahan bobot badan hingga $0.7-0.9 \mathrm{~kg} /$ hari pada pemberian ransum dengan kandungan protein kasar $12.2 \%$ $15.3 \%$.

Pertambahan berat badan pada penelitian ini termasuk cukup tinggi dibandingkan dengan laporan Akbarillah dan Hidayat (2009) yang menyatakan bahwa sapi Bali menghasilkan pertambahan bobot badan harian $(\mathrm{PBBH})$ 0,13 kg/ekor/hari dan penelitian yang dilakukan (Wijaya, 2008) yaitu rata-rata pertambahan berat badan sapi potong hanya mencapai 0,156 kg/ekor/hari. Hal ini dapat disebabkan oleh kecernaan pakan sapi penelitian tinggi sehingga mengakibatkan pertambahan bobot badan menjadi tinggi. Hal ini sesuai dengan pendapat Crowder dan Chheda (1982) bahwa makin tinggi kecernaan suatu pakan, maka memungkinkan lebih banyak nutrien yang dapat diserap. McDonald et al. (1995) menyatakan bahwa kecernaan atau daya cerna suatu bahan pakan diasumsikan sebagai zat makanan yang tidak dieksresikan di dalam feses, tetapi diabsorbsi oleh ternak..

Pertambahan berat badan sapi bali jantan lebih tinggi dengan waktu penggemukan yang relatif singkat apabila sapi diberi ransum yang terdiri dari konsentrat dan hijauan. 
Sejalan dengan Yulianto (2012), bahwa pemberian pakan hijauan pada penggemukan sapi tidak akan memberikan pengaruh yang signifikan terhadap pertambahan berat badan yang tinggi dalam waktu yang singkat.

Perbedaan pertambahan berat badan sapi bali jantan disetiap perlakuan ditentukan oleh jumlah pakan yang dikonsumsi selain itu rendahnya berat badan yang diperoleh mungkin disebabkan oleh faktor manajemen dan konsumsi pakan serta kandungan gizi pakan. Menurut Campbell et al., (2003), perbedaan menggunakan pakan tiap perlakuan secara efesien dipengaruhi beberapa faktor antara lain kemampuan ternak dalam mencerna bahan pakan, kecukupan zat pakan untuk hidup pokok, pertumbuhan, dan fungsi tubuh serta jenis pakan yang digunakan.

Dengan dua perlakuan dan 5 kali ulangan menghasilkan rataan berat badan pada sapi bali jantan dengan perlakuan penambahan rumput laut (sargassum sp.) 162,64 kg dibandingkan dengan berat badan sapi bali jantan tanpa penambahan rumput laut (sargassum sp) 160,16 kg.

Perbedaan rata-rata berat badan yang diperoleh disebabkan jumlah pakan dan kandungan gizi yang dikonsumsi oleh masing-masing ternak tersebut berbeda. Selain itu salah satu factor meningkatnya berat badan sapi bali jantan dapat dipengaruhi oleh tingkat konsumsi pakan, maka sapi yang mengalami kekurangan konsumsi pakan, berat badannya akan terhambat.

Menurunnya berat badan sapi bali jantan pada penelitian ini mungkin disebabkan oleh cuaca yang tidak menetap dan angin kencang, kandang yang terbuka, tata cara pemeliharaan lainnya yang kurang baik. Fitriah (2013) menyatakan bahwa penyebab utama rendahnya produktivitas dari ternak sapi Bali adalah pola pemeliharaan yang sebagian besar dipelihara oleh masyarakat pedesaan secara tradisional serta manajemen ternak yang rendah dan kurang terarah, dimana peternak belum memperhatikan mutu pakan, tata cara pemeliharaan, perkandangan dan penyakit sehingga pola pertumbuhan ternak pada umur pertumbuhan kurang optimum. Menurut Siregar (2008) bahwa tujuan pembuatan kandang adalah pertama-tama diupayakan untuk melindungi sapi terhadap gangguan luar yang merugikan baik terhadap sengatan terik matahari,kedinginan, kehujanan, tiupan angin yang dingin.

\section{KESIMPULAN}


Berdasarkan hasil dan pembahasan dapat disimpulkan : pemberian Alga Coklat (Sargassum sp.) sebagai pakan konsentrat sebesar $15 \%$ tidak berbeda nyata $(\mathrm{P}>0,05)$ terhadap pertambahan berat badan sapi bali jantan. Pada penelitian selanjutnya persentase penambahan Alga Coklat (Sargassum sp.) sebaiknya ditingkatkan diatas dari 15\%, karena Alga Coklat (Sargassum sp.) memiliki potensi untuk mengoptimalkan perubahan pertambahan berat badan, konsumsi pakan cenderung meningkat seiring dengan lamanya waktu perlakuan. Pada pemanfaatan pakan baru setidaknya dilakukan pembiasaan untuk memaksimalkan konsumsi pakan memerlukan waktu cukup lama (kurang lebih 3 bulan untuk pembiasaan) pada sapi bali jantan.

\section{DAFTAR PUSTAKA}

Akbarillah, T dan Hidayat, H. 2009. Pengaruh pemanasan bungkil inti sawit dalam pakan berbasis pelepah sawit dan hasil ikutan pabrik pengolahan sawit terhadap penampilan sapi. J. Indon. Trop. Anim. Agric 34, 28-35 .

Campbell, J. R., Kenealy, M. D. dan Campbell, K.L. 2003. Animal Sciences. The Biology, Care, and Production of Domestic Animals. 4th Edition. McGraw-Hill, London.

Crowder, L.V. dan H.R. Chheda. 1982. Tropical Grassland Husbandry. Longman Inc., New York.

Direktorat Jenderal Produksi Peternakan. 2000. Pedoman Budidaya Sapi Potong yang Baik (Good Farming Practices). Jakarta.

Fitriah. 2013. Pertambahan Berat Badan Sapi Bali Pada Umur Berbeda yang Dipelihara Secara Intensif. Skripsi. Fakultas Peternakan Universitas Hasanuddin. Makassar.

Hardianto, R. 2000. Teknologi Complete Feed Sebagai Alternatif Pakan Ternak Ruminansia. Makalah BPTP Jawa Timur, Malang.

Oematan, J.S. 2000. Pertumbuhan kompensasi Sapi Bali Jantan pada beberapa imbangan energi:protein ransum dan efeknya terhadap sifat-sifat karkas. Tesis. Bogor (ID): Institut Pertanian Bogor.

Pane, I., 1991. Produktivitas dan breeding Sapi Bali. Proceeding Seminar Nasional Sapi Bali. 2-3 September 1991;Ujung Pandang, Indonesia.Ujung Pandang (ID): Fakultas Peternakan Universitas Hasanuddin.

Putri, K. H. 2011. Pemanfaatan Rumput Laut Coklat (Sargassum sp.) Sebagai Serbuk Minuman Pelangsing Tubuh. Skripsi. Departemen teknologi Hasil Perairan. Fakultas Perikanan dan Ilmu Kelautan. Institut Pertanian Bogor. Bogor.

Rahmat, R. 1999. Kandungan dan Karakteristik Fisiko K imia Alginat dariSargassum sp. Yang Dikumpulkan dari Perairan Indonesia. Jakarta:Laboratorium Produk Alam Laut, Puslitbang Oseanologi LIPI. Jakarta.

Saputra T., Triatmojo S., dan Pertiwiningrum, A. 2010. Produksi Biogas dari Campuran Feses Api dan Ampas Tebu (Bagasse) dengan Rasio C/N yang Berbeda. Fakultas Peternakan. Universitas Gajah Mada. Yogyakarta.

Siregar, S. B. 2008. Penggemukan Sapi Edisi Revisi. Penebar Swadaya, Jakarta. 
Umiyasih. U. dan Y.N. Anggraeny 2007. Petunjuk Praktis Ransum Seimbang, Strategi Pakan Pada Sapi Potong. Badan Penelitian dan Pengembangan Peternakan. Departement Pendidikan. Jakarta.

Widowati I, Susanto A.B., Stiger-Pouvreau V., and Bourgougnon N. 2013. Potentiality of Using Spreading Sargassum Species from Jepara, Indonesia as an Interesting Source of Antibacterial and Antioxidant Compounds: a Preliminary Study $21^{\text {st }}$ International Seaweed Symposium. Seaweed Science for Sustainable Prosperity. Bali.

Wijaya. A. 2008. Pengaruh Imangan Hijauan dan Konsentrat Berbahan baku Limbah Pengolahan Hasil Pertanian dalam Ransum Terhadap Penampilan Sapi FSH Jantan. Skripsi. Universitas Sebelas Maret. Surakarta.

Yulianto, P. 2012. Penggemukan Sapi Potong. Penebar Swadaya. Jakarta. 